

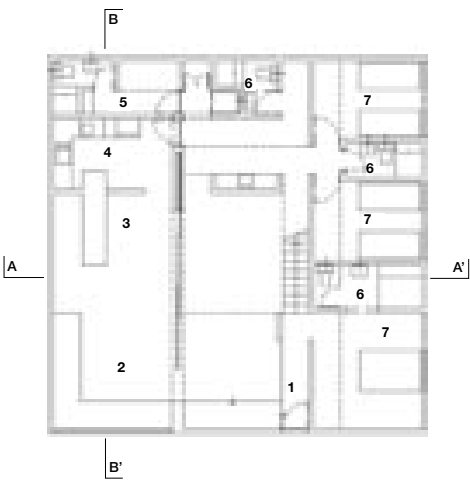

Planta primer nivel

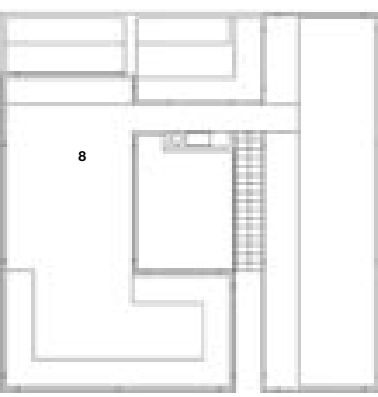

Planta segundo nive
$A^{\prime}$

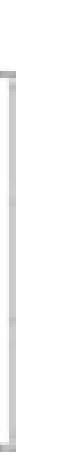

$\left(\frac{10}{2}\right.$

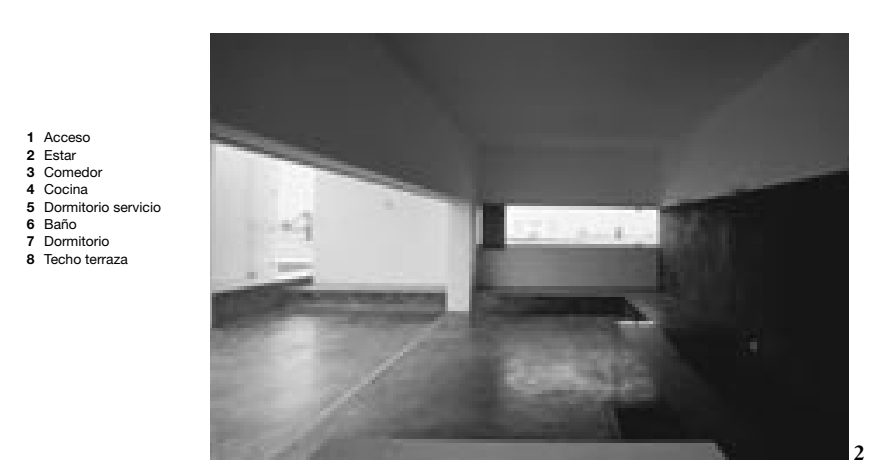

1 El volumen en el predio
Al fondo, las torres de
agua del loteo
2 Vista desde la cocina

2 Vista desde la cocin
al comedor

3 Comedor, vista hacia la cocina

4 Estar y patio central

5 Vista del techo terraza y

las pérgolas vecinas
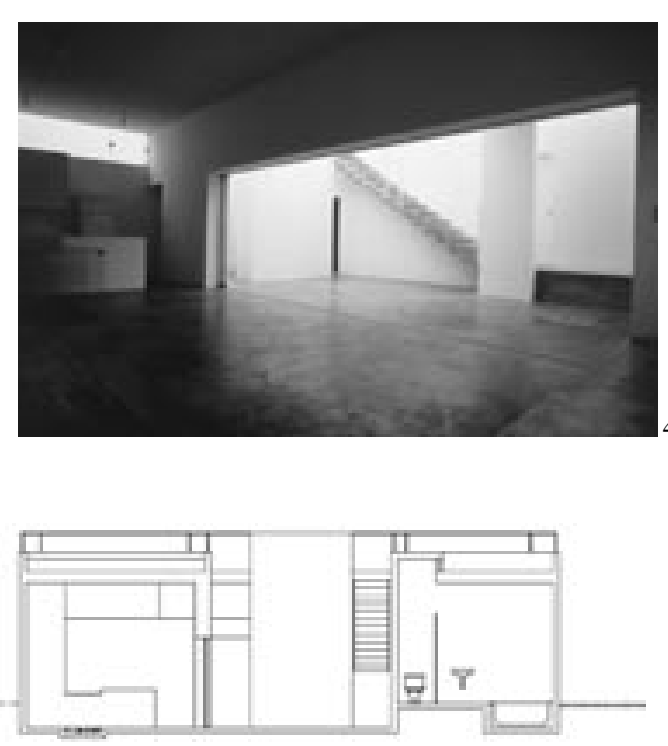

Corte A-A

su mínimo espesor, tarrajeados y pintados en blanco, organizados por su geometría. La falta de lluvias permite emplear el cristal templado empotrado en ellos sin carpintería, mejorando la relación exterior - interior.

Se emplean pisos y zócalos de cemento pulido con ocres incluidos en su mezcla, sellados y encerados, como también hormigón visto en la escalera apoyada en dos puntos y pletinas de fierro como barandas.

En la costa sur, donde la madera es escasa y la piedra es de pequeñas dimensiones, la construcción tradicional ha sido de adobe y quincha, mientras que la tradición de la madera y la piedra han tenido un desarrollo restringido. El sistema porticado de concreto con ladrillo, utilizado en la casa, fue adoptado en el desierto como una evolución natural de aquel sistema. El clima temperado, húmedo, falto de lluvias, no ha necesitado de una construcción compleja, cosa que se manifiesta en sus detalles. Los techos son planos y los muros sólo protegen la casa del sol y del viento arenado.

La arquitectura se convierte en el orden que articula la propia naturaleza del desierto en el tiempo, creando una comunicación permanente y fluida con sus habitantes. ARQ
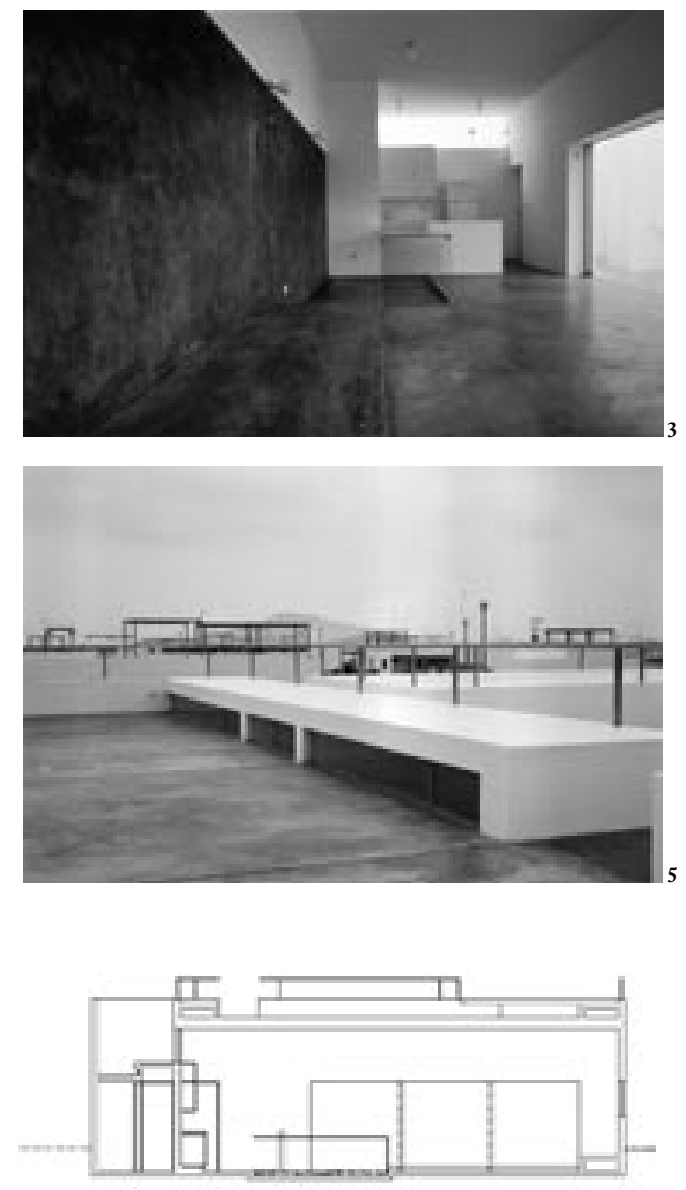

Corte B-B'

\section{Casa en Playa Bonita}

Arquitecta Alexia León

Colaborador Germán Beingolea

Ubicación Carretera Panamericana Sur Km 99,

Lote 11, Línea H, Distrito de Asia, Lima, Perú

Cliente Mario Mori

Cálculo estructural Javier Martín Arranz

Construcción Santos Palacios

Instalaciones eléctricas Felipe del Risco

Instalaciones sanitarias Enrique Bastante

Materialidad Muros de albañilería reforzada

estucada, cristal templado, pavimentos

de radier pulido de color, hormizón visto

Presupuesto de la obra Reservado

Superficie terreno 156,25 m²

Superficie proyecto 156,25 $\mathrm{m}^{2}$ (primer nivel),

$133,16 \mathrm{~m}^{2}$ (techo terraza)

Año proyecto 1996

Año construcción 1996

Fotografía Juan Enrique Bedoya

Imágenes digitales Karim Wons reconocibles tanto para el maestro como para los albañiles locales, así como materiales comunes de bajo costo manejados de forma convencional, en estrecha relación con el clima de la costa y con la lógica de la casa.

Se emplean muros de albañilería que exponen 